\title{
Role of mitogen-activated protein kinase and phosphoinositide 3-kinase in the differentiation of rat pancreatic AR42J cells induced by hepatocyte growth factor
}

\author{
M. Furukawa, Y. Q. Zhang, L. Nie, H. Shibata, I. Kojima \\ Institute for Molecular and Cellular Regulation, Gunma University, Maebashi, Japan
}

\begin{abstract}
Aims/hypothesis. Pancreatic AR42J cells express both exocrine and neuroendocrine properties. When exposed to activin A, approximately $50 \%$ of the cells die within 3 days by apoptosis. Addition of hepatocyte growth factor prevents apoptosis induced by activin A and induces differentiation into insulin-producing cells. The present study was conducted to examine the role of mitogen-activated protein kinase and phosphoinositide 3-kinase in the action of hepatocyte growth factor.

Methods. The role of mitogen-activated protein kinase was assessed by using 2-(2'-amino-3'-methoxyphenol)-oxanaphthalen-4-one (PD098059). Cells were also transfected with cDNA for mitogen-activated protein kinase phosphatase and constitutively active mutant of mitogen-activated protein kinase kinase.

Results. Hepatocyte growth factor induced sustained activation of the mitogen-activated protein kinase, which was inhibited by PD098059. PD098059 com-
\end{abstract}

pletely blocked the differentiation and also blocked the prevention of apoptosis. Transfection of the cells with cDNA for mitogen-activated protein kinase phosphatase reproduced the effect of PD098059. Conversely, transfection with cDNA for the constitutively active mutant of mitogen-activated protein kinase kinase reproduced the effect of hepatocyte growth factor. In contrast, addition of wortmannin or transfection of the dominantly negative form of the p85 subunit of the phosphoinositide 3-kinase did not affect differentiation induced by hepatocyte growth factor. Instead, wortmannin enhanced the increase in the insulin content of the differentiated AR42J cells. Conclusion/interpretation. The MAP kinase pathway is necessary and sufficient for the action of HGF on differentiation of AR42J cells. [Diabetologia (1999) 42: 450-456]

Keywords Insulin, beta cell, differentiation, hepatocyte growth factor, MAP kinase.
Pancreatic endocrine and exocrine cells are thought to arise from the common precursor cells during development $[1,2]$. Neogenesis of endocrine cells from the

Received: 24 August 1998 and in final revised form: 16 November 1998

Corresponding author: I. Kojima, M.D., Institute for Molecular and Cellular Regulation, Gunma University, Maebashi 371-8512, Japan

Abbreviations: HGF, Hepatocyte growth factor; MAP, mitogen-activated protein; PI, phosphoinositide; ICC, islet celllike cluster; MAPKK, mitogen-activated protein kinase kinase; GFP, green fluorescent protein; PD098059, 2-(2'-amino3 '-methoxyphenol)-oxanaphthalen-4-one; LY294002, 2-(4morpholinyl)-8-phenyl-4H-1-benzopyran-4-one. progenitor in the pancreatic duct also occurs after the destruction of pancreatic beta cells in adult animals. The precise differentiation process and the mechanism regulating the differentiation of pancreatic beta cells are of considerable interest. The formation of pancreatic endocrine cells is presumed to be determined by sequential activation of various transcription factors and several transcription factors regulating differentiation of pancreatic endocrine cells have been postulated [3-6]. It is also conceivable that various extracellular signalling molecules regulate the formation and differentiation of pancreatic endocrine cells. Thus, various growth and differentiation factors are thought to be involved in the formation, proliferation and differentiation of pancreatic endocrine cells. 
Pancreatic AR42J cells are derived from rat pancreatic acinar tumours and possess both exocrine and neuroendocrine properties [7]. Upon treatment with activin A, AR42J cells differentiate into cells with neuron-like morphology [8]. In addition to the morphological changes, activin treatment leads to the expression of the ATP-sensitive potassium channel and furthermore, the expression of a pancreatic hormone, pancreatic polypeptide [8,9]. Hence, activin A converts amylase-secreting AR42J cells into endocrine cells. Activin-treated AR42J cells further differentiate into insulin-producing cells by treatment with either betacellulin [9] or hepatocyte growth factor (HGF) [10]. Taken together, AR42J cells could be a useful model system to study the formation of insulinproducing cells from the common precursor cells.

Hepatocyte growth factor (HGF) is a multifunctional factor that modulates growth, differentiation, motility, and organogenesis [11, 12]. It is synthesized in mesenchymal cells and has been shown to increase the number of insulin-producing cells in cultured human islet cell-like clusters (ICC) [13]. It also mediates beta-cell mitogenic signals from the fetal mesenchyme to the developing beta cell [14] and is possibly one of physiological regulators of differentiation of pancreatic endocrine cells. In this study, we investigated the signal transduction pathways responsible for the formation and maturation of insulin-producing cells from AR42J cells induced by HGF.

\section{Materials and methods}

Materials. Recombinant human HGF was purchased from $\mathrm{R}$ and D Systems (Minneapolis, Minn., USA) and epidermal growth factor (EGF) was from Collaborative Research (Lexington, Mass., USA). Recombinant human activin A was supplied by Dr. Y. Eto of Central Research Laboratory, Ajinomoto (Kawasaki, Japan). The 2-(2'-amino-3 '-methoxyphenol)-oxanaphthalen-4-one (PD098059), which inhibits the activation of mitogen activated protein kinase kinase (MAPKK) by Raf1 [15], was provided by Dr. A. Saltiel of Parke-Davis (Ann Arbor, Mich., USA). Wortmannin was from Sigma Chemicals (St. Louis, Mo., USA) and was dissolved in dimethyl sulphoxide at a concentration of $10 \mathrm{mmol} / \mathrm{l}$. The 2-(4-morpholinyl)-8phenyl-4H-1-benzopyran-4-one (LY294002) was from Calbiochem (La Jolla, Calif., USA). The materials required for the assay of mitogen-activated protein (MAP) kinase activity (including specific peptide substrate) and $\left[\gamma_{-}{ }^{32} \mathrm{P}\right]$ ATP were provided by Amersham Pharmacia Biotech, (Amersham Bucks, UK). Dr. E. Nishida of Kyoto University (Kyoto, Japan) provided cDNAs encoding MAP kinase phosphatase and constitutively active mutant of MAPKK. Dr. M. Kasuga of Kobe University (Kobe, Japan) provided cDNA encoding dominantly negative mutant of p85 subunit of PI 3-kinase.

Cell culture. We used AR42J-B13 cells, a subclone of AR42J, which convert into insulin-positive cells in response to HGF and activin A [10]. These cells were maintained in DMEM containing $20 \mathrm{mmol} / \mathrm{l} \mathrm{HEPES} / \mathrm{NaOH}$ (pH 7.4), $5 \mathrm{mmol} / 1 \mathrm{NaHCO}_{3}$, penicillin, streptomycin and $10 \% \mathrm{FCS}$ at $37^{\circ} \mathrm{C}$ under a humidified condition of $95 \%$ air and $5 \% \mathrm{CO}_{2}$. The number of viable cells was counted after staining the cells with acrydine orange/ ethidium bromide [16]. This method makes non-viable cells visible but does not discriminate apoptotic cells from necrotic cells.

Measurement of MAP kinase activity. We seeded AR42J-B13 cells at a density of $2 \times 10^{5}$ cells/ml in 6-well dishes (Falcon, Becton Dickinson, Lincoln Park, N.J., USA). Cells were serum-starved for $24 \mathrm{~h}$ and then incubated with $\mathrm{HGF}$, EGF, insulin or activin $\mathrm{A}$ for the time indicated at $37^{\circ} \mathrm{C}$. To examine the effects of PD098059, cells were pretreated with the compound for $60 \mathrm{~min}$ and then HGF was added. The cells were further incubated for various times. After the treatment, cells were harvested by scraping in $400 \mu \mathrm{l}$ of lysis buffer containing $10 \mathrm{mmol} / \mathrm{l}$ TRIS/HCl ( $\mathrm{pH} 7.4), 150 \mathrm{mmol} / \mathrm{l} \mathrm{NaCl}, 2 \mathrm{mmol} / \mathrm{l}$ pheylmethylsulphonyl fluoride, $10 \mu \mathrm{g} / \mathrm{ml}$ leupeptin and $10 \mu \mathrm{g} /$ $\mathrm{ml}$ aprotinin. Cellular debris were precipitated by centrifugation at $25,000 \times g$ for $20 \mathrm{~min}$ and the supernatant was retained to obtain cytoplasmic MAP kinase. Samples $(15 \mu \mathrm{l})$ and $10 \mu \mathrm{l}$ of the substrate buffer containing $6 \mathrm{mmol} / \mathrm{l}$ specific substrate were added to each tube together with $5 \mu$ of $\left[\gamma_{-}{ }^{32} \mathrm{P}\right]$ ATP (37 $\mathrm{KBq}(1.0 \mu \mathrm{Ci})$ of $\left.\left[\gamma_{-}{ }^{32} \mathrm{P}\right] \mathrm{ATP}\right)$ and $9 \mathrm{mmol} / \mathrm{l} \mathrm{MgCl}_{2}$ and incubated for $30 \mathrm{~min}$ in a water bath at $30^{\circ} \mathrm{C}$. The reaction was terminated by adding $10 \mu \mathrm{l}$ of $300 \mathrm{mmol} / \mathrm{l}$ orthophosphoric acid. From each sample $30 \mu \mathrm{l}$ was spotted onto a phosphocellulose disc, washed three times in $0.5 \%$ phosphoric acid for $30 \mathrm{~min}$ and once in distilled water for $5 \mathrm{~min}$. The radioactivity on each disc was then determined by scintillation counting [17].

Measurement of phosphoinositide 3-kinase activity. Cells were incubated for various times with HGF in the presence and absence of wortmannin. The cells were rinsed with an ice-cold buffer containing $20 \mathrm{mmol} / \mathrm{l}$ HEPES/NaOH ( $\mathrm{pH}$ 7.5), $150 \mathrm{mmol} / 1 \mathrm{NaCl}$, and $0.1 \mathrm{mmol} / 1 \mathrm{Na}_{3} \mathrm{VO}_{4}$ and then lysed in $300 \mu \mathrm{l}$ of this buffer supplemented with $10 \%$ glycerol, $1 \%$ Nonidet P-40 (Sigma Chemicals), $5 \mathrm{mmol} / \mathrm{l}$ EDTA, $1 \mathrm{mmol} / \mathrm{l}$ phenylmethylsulphonyl fluoride, $10 \mu \mathrm{g} / \mathrm{ml}$ leupeptin and $10 \mu \mathrm{g} / \mathrm{ml}$ pepstatin A. The cell lysates were centrifuged at $25,000 \times g$ for 20 min and the supernatant was immunoprecipitated with an anti-phosphotyrosine antibody coupled to protein G-sepharose. Phosphoinositide (PI) 3-kinase activity in the immunoprecipitate was measured as described previosly [18].

Transfection of $c D N A$. We seeded AR42J-B13 cells on noncoated glass cover slips and cultured them for $20 \mathrm{~h}$ before transfection. Then $2 \mu \mathrm{g} /$ well of the transient expression vector containing SV40 promoter encoding constitutively active mutant of MAP kinase kinase (pcDL-SR $\alpha 456,32-51$ S218E S222E MAPKK) and of encoding MAP kinase phosphatase ( $\mathrm{SR} \alpha$ 456-CL100) were transfected with a liposome method using LIPOFECTAMINE Regent (Gibco, Gland Island, N. Y., USA). Cells were co-transfected with $0.2 \mu \mathrm{g} /$ well plasmid pGL-1 containing cytomegalo-virus promoter encoding green fluorescent protein (GFP) (Gibco) [19] to effectively monitor transfected cells. Efficiency of transfection was 15-30\%.

Antibodies. Polyclonal antibody against insulin was provided by Dr. K. Wakabayashi of the Institute for Molecular and Cellular Regulation, Gunma University (Maebashi, Japan). As a second antibody, we used indocarbocyanine-conjugated donkey anti-guinea pig IgG (Cappel, Turnhout, Belgium) [9].

Immnofluorescence microscopy. Cells were cultured on noncoated glass coverslips. To examine the effects of PD098059 or wortmannin on producing insulin-positive cells, AR42JB13 cells were pretreated with the compound for $60 \mathrm{~min}$. The cells were then cultured with $100 \mathrm{pmol} / \mathrm{l}$ of $\mathrm{HGF}$ and $4 \mathrm{nmol} / \mathrm{l}$ activin A for $72 \mathrm{~h}$ with and without PD098059 or wortmannin. 

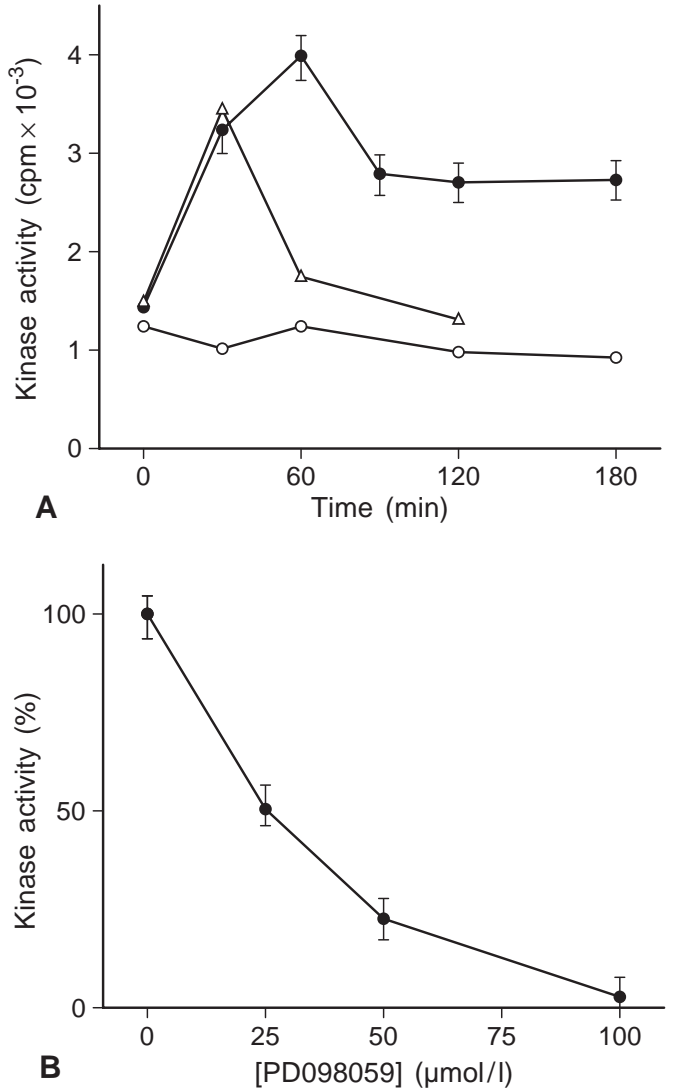

Fig.1A, B. Effect of HGF on the activity of MAP kinase. A AR42J-B13 cells were incubated for indicated time with (O) or without $(\bigcirc) 100 \mathrm{pmol} / 1 \mathrm{HGF}$ or $1 \mathrm{nmol} / \mathrm{l} \mathrm{EGF}(\triangle)$ and the activity of MAP kinase was measured as described in the Methods. Values are the means \pm SD for four experiments each done in duplicate. B AR42J-B13 cells were incubated for $60 \mathrm{~min}$ with $100 \mathrm{pmol} / \mathrm{l} \mathrm{HGF}$ and various concentrations of PD098059. The MAP kinase activity was then measured. Values are the means \pm SD for four experiments

Cells transfected with cDNA for constitutively active mutant of MAP kinase kinase were cultured with or without $4 \mathrm{nmol} /$ 1 activin A and cells transfected with cDNA for MAP kinase phosphatase were cultured with $100 \mathrm{pmol} / \mathrm{l} \mathrm{HGF}$ and 4 nmol/l activin A for $24 \mathrm{~h}$. The cells were fixed with $3 \%$ paraformaldehyde in PBS for $30 \mathrm{~min}$, permeabilized with $0.1 \%$ (vol/vol) Triton X-100 in PBS for $5 \mathrm{~min}$ and incubated sequentially with Block Ace (Morinaga, Tokyo, Japan) for blocking, the first antibody (anti-insulin; 1:500) and the second antibody (1:1500). The cells were examined with an Olympus BX50 microscope equipped with a BX-fluorescence attachment and dual-band filter (U-MFI/TRITC) (Olympus Optical, Tokyo, Japan). For measurement of insulin-positive cells, incubation was in quadruplicate and 500 cells were counted in each dish.

Measurement of insulin content. Cells were incubated with activin $\mathrm{A}$ and HGF for $72 \mathrm{~h}$. Then the cells were washed with DMEM and were further incubated with HGF for 5 days in the presence and absence of wortmannin. Cells were lysed by sonication and insulin was extracted using $0.1 \mathrm{~mol} / \mathrm{l} \mathrm{HCl}$. Insulin content of the cells was measured by using a time-dissolved immunofluorometric assay system [9]. The statistical significance was determined by Student's $t$ test.
Reverse transcription-PCR. We extracted mRNA by using the Quick Prep (Pharmacia, Piscataway, N.J., USA). Samples of mRNA were treated with DNase to remove any trace of contamination by genomic DNA. First-stranded cDNA was synthesized by using a preamplification system for First Stand cDNA Synthesis Kit (Gibco). To confirm that there was no contamination of genomic DNA, samples without reversetranscriptase treatment were prepared. We carried out PCR as described previosly [9].

\section{Results}

Effect of HGF on MAP kinase and PI 3-kinase activities. Hepatocyte growth factor activates various intracellular signalling pathways. In this study, we investigated the role of MAP kinase and PI 3-kinase in the action of HGF on differentiation of AR42J cells. We first examined the effects of HGF on the activities of MAP kinase and PI 3-kinase. We found, $100 \mathrm{pmol} / \mathrm{l}$ HGF increased the MAP kinase activity in AR42J cells (Fig. 1A). The effect of HGF was biphasic. The MAP kinase activity was at a maximum at $60 \mathrm{~min}$, reached the plateau level at $90 \mathrm{~min}$ and remained raised for at least $180 \mathrm{~min}$ (Fig. 1A). The effect of HGF was sustained but the effects of other growth factors, for example EGF and insulin (data not shown) were only transient although the peak value was nearly identical. The MAP kinase activity after EGF or insulin peaked at 30 min but returned to the basal level by $60 \mathrm{~min}$. AR42J cells differentiate into insulin-producing cells by a combination of HGF and activin A [10]. Activin A did not affect the MAP kinase activity by itself or alter the effect of HGF (data not shown). The activation of MAP kinase kinase induced by Raf-1 is inhibited by PD098059 [15]. We found PD098059 inhibited HGF-induced activation of the MAP kinase in a concentration-dependent manner (Fig.1B). At $100 \mu \mathrm{mol} / \mathrm{l}$, PD098059 nearly completely blocked the activity of MAP kinase.

A rapid activation of PI 3-kinase was induced by HGF (Fig. 2). Wortmannin is a compound which blocks the activity of PI 3-kinase at concentrations around $100 \mathrm{nmol} / 1$ [20]. We found $100 \mathrm{nmol} / 1$ wortmannin completely inhibited the PI 3-kinase activated by HGF in AR42J cells (Fig. 2).

Effect of PD098059 and wortmannin on the formation of insulin-producing cells. To assess the involvement of MAP kinase or PI 3-kinase or both in HGFinduced differentiation, we examined the effects of PD098059 and wortmannin on the formation of insulin-producing cells induced by a combination of HGF and activin A. After treatment with activin $\mathrm{A}$ and HGF for $72 \mathrm{~h}$ AR42J cells convert to insulin-producing cells [10]. When cells were incubated for $72 \mathrm{~h}$ with activin $\mathrm{A}$ alone, the cells began to synthesize pancreatic polypeptide $[8,9]$. The morphology of the cells changed considerably [8] but we found the num- 

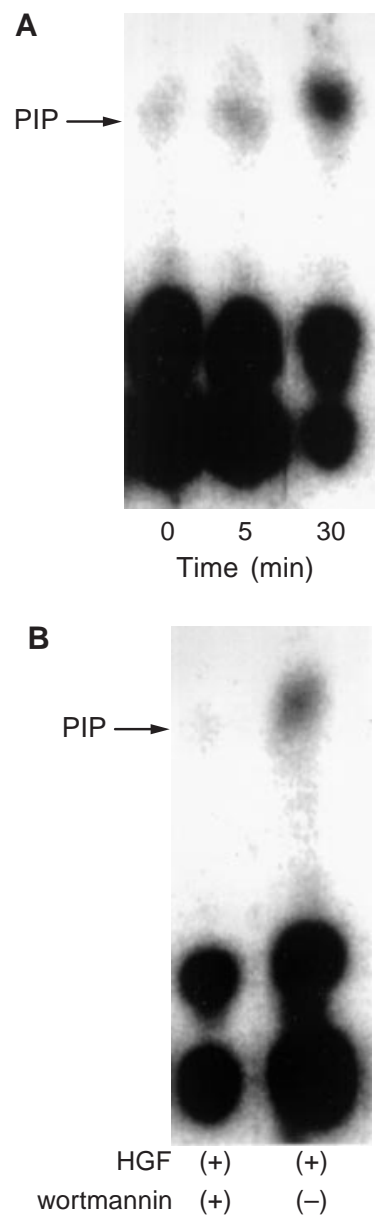

Fig. 2A, B. Effect of HGF on the activity of PI 3-kinase. A AR42J-B13 cells were incubated for 5 min with $100 \mathrm{pmol} / \mathrm{l}$ $\mathrm{HGF}$ and the activity of PI 3-kinase was measured as described in the Methods. The result is representative of three experiments. B AR42J-B13 cells were incubated with $100 \mathrm{pmol} / 1$ $\mathrm{HGF}$ in the presence and absence of $100 \mathrm{nmol} / \mathrm{l}$ wortmannin and the activity of PI 3-kinase was measured. The result is representative of two experiments

ber of living cells were greatly reduced (Fig.3). Activin $A$ induced apoptosis since DNA ladder formation was observed in cells treated with activin A (data not shown). Addition of HGF blocked the reduction of the number of living cells induced by activin A (Fig. 3) and further induced differentiation into cells expressing insulin. Most of the AR42J cells treated with HGF and activin A for $72 \mathrm{~h}$ became insulin-positive. Addition of $50 \mu \mathrm{mol} / \mathrm{l}$ PD098059 blocked the formation of insulin-producing cells. At this concentration of PD098059, the number of living cells was slightly reduced. There was a dose-response relation for PD098059-induced inhibition of the effect of HGF (Fig. 4). Incubation of AR42J cells with a combination of activin A- and HGF-induced differentiation in about $80 \%$ of the cells (Fig. 4). PD098059 inhibited HGF-induced differentiation in a concentration-dependent manner. It also inhibited the expression of mRNA for insulin induced by HGF (Fig.5).

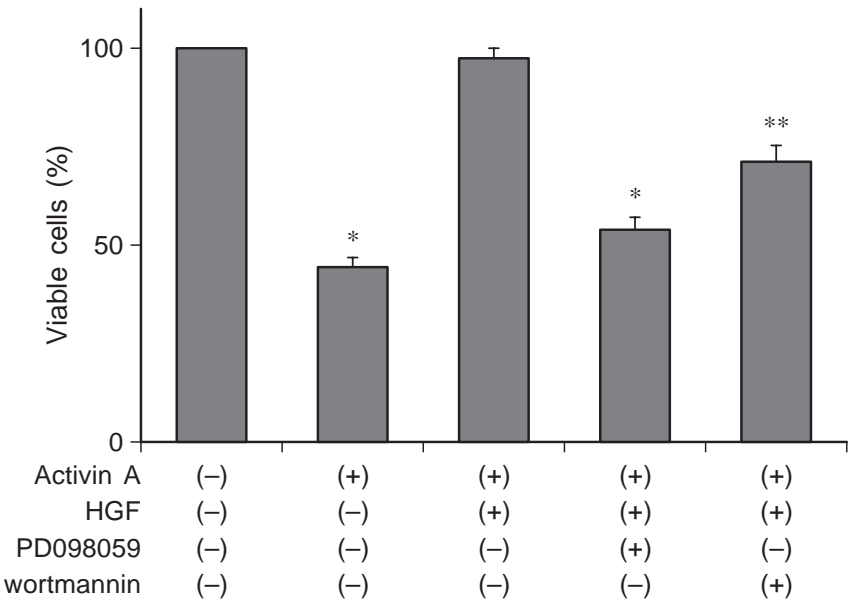

Fig. 3. Effect of activin A and $\mathrm{HGF}$ on the viability of AR42J cells. AR42J-B13 cells were incubated with $4 \mathrm{nmol} / \mathrm{l}$ activin A in the presence and absence of $100 \mathrm{pmol} / \mathrm{l} \mathrm{HGF}$ for 3 days and the number of living cells was counted. In some experiments, $100 \mu \mathrm{mol} / \mathrm{l} \mathrm{PD} 098059$ or $100 \mathrm{nmol} / \mathrm{l}$ wortmannin was added. Values are the means \pm SD for four experiments. $* P<0.01$ vs none, $* * P<0.05$ vs none

As noted above, $100 \mu \mathrm{mol} / 1$ PD098059 completely blocked HGF-induced differentiation but at this concentration, the number of living cells was reduced by approximately $50 \%$ (Fig. 3).

In contrast, AR42J cells converted to insulin-positive cells even in the presence of $100 \mathrm{nmol} / \mathrm{l}$ wortmannin (data not shown) and mRNA for insulin was detected in the presence of wortmannin (Fig.5). Since wortmannin is relatively unstable, we added it every $24 \mathrm{~h}$ in some experiments, but the results were the same. Furthermore, similar results were obtained by using LY294002, another inhibitor of PI 3-kinase (data not shown). Note that wortmannin reduced the number of living cells (Fig. 3).

Effect of transfection of cDNA for MAP kinase phosphatase and constitutively active mutant of MAP kinase kinase. To confirm the involvement of MAP kinase in the HGF-induced differentiation, we transfected cells with cDNA for MAP kinase phosphatase, which blocks the activation of the MAP kinase [21]. We transfected AR42J cells with cDNA for MAP kinase phosphatase together with that for GFP. Cells that effectively transfected were identified by green fluorescence of GFP. Both transfected and untransfected cells were incubated for $24 \mathrm{~h}$ with a combination of HGF and activin A. Transfected cells expressing GFP did not express immunoreactive insulin whereas cells not transfected effectively expressed insulin (Fig. 6). Immunoreactivity of insulin disappeared in all the cells effectively transfected with GFP (Table 1).

We also transfected AR42J cells with cDNA for constitutively active mutant of MAPKK, which activates MAP kinase [22]. Cells were transfected with 


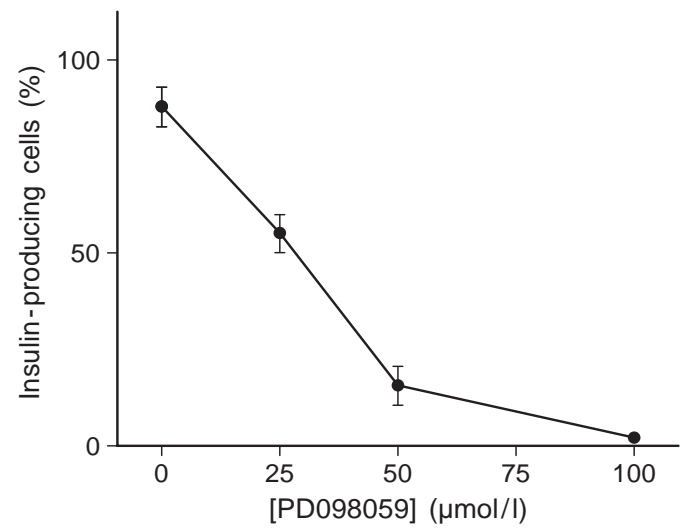

Fig. 4. Dose-response relation for PD098059-induced inhibition of differentiation. AR42J-B13 cells were incubated for 3 days with $100 \mathrm{pmol} / \mathrm{l} \mathrm{HGF}$ and $4 \mathrm{nmol} / \mathrm{l}$ activin A in the presence of various concentrations of PD098059. The number of insulin-producing cells was examined by immunocytochemistry. Values are the means \pm SD for four experiments

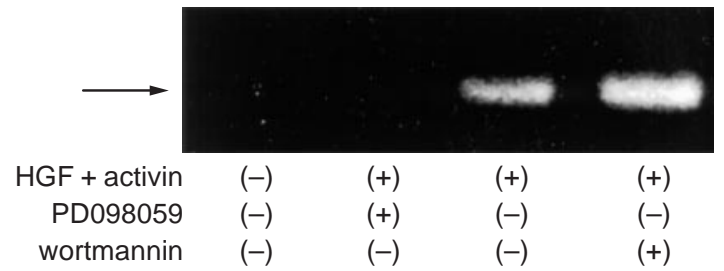

Fig.5. Expression of mRNA for insulin. AR42J-B13 cells were incubated for 3 days with $100 \mathrm{pmol} / \mathrm{l} \mathrm{HGF}$ and $4 \mathrm{nmol} / \mathrm{l}$ activin $\mathrm{A}$ in the absence and presence of $100 \mu \mathrm{mol} / \mathrm{l}$ PD098059 or 100 nmol/l wortmannin. RNA was extracted and mRNA for insulin was measured by RT-PCR

cDNA for constitutively active mutant of MAPKK together with cDNA for GFP. Both transfected and untransfected cells were incubated for $24 \mathrm{~h}$ with activin $A$ and effectively transfected cells were identified by fluorescence of GFP. Effectively transfected cells incubated with activin A became insulin-positive (Fig. 6). Immunoreactivity of insulin was detected in more than $80 \%$ of the cells expressing GFP (Table 1). Transfected cells did not become insulin-positive in the absence of activin A treatment (data not shown). To confirm the absence of an involvement of PI 3-kinase in the action of HGF on differentiation, we introduced cDNA for dominantly negative mutant of p85 subunit of the PI 3-kinase [23] together with that for GFP. Cells transfected with the dominantly negative $\mathrm{p} 85$ converted to insulin-positive cells when incubated with HGF and activin A (Table 1).

Blockers of PI 3-kinase have been reported to enhance the differentiation of ICC [24]. We therefore further studied whether wortmannin altered the effect of HGF. We found AR42J cells converted to insulin-producing cells after the treatment with activin $\mathrm{A}$ and HGF for $72 \mathrm{~h}$. Once differentiated, however,
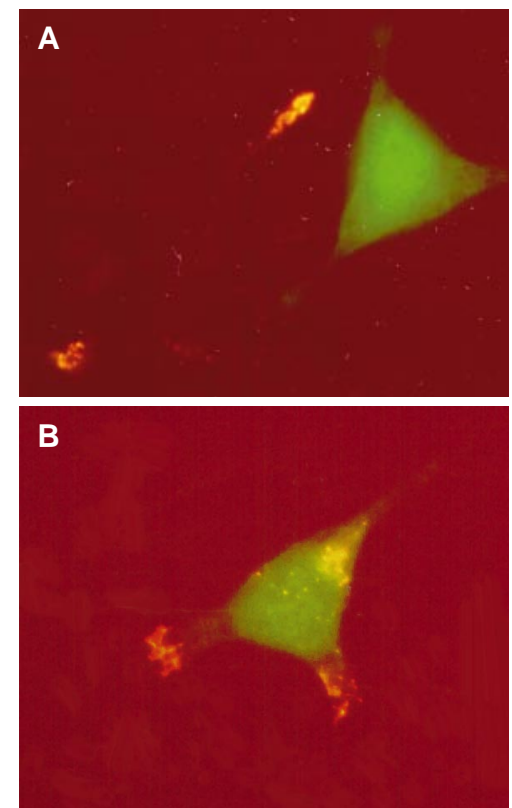

Fig.6A, B. Effect of transfection of MAP kinase phosphatase and constitutively active MAPKK on differentiation. A AR42J-B13 cells were co-transfected with cDNA for MAP kinase phosphatase and GFP. The cells were then incubated with $100 \mathrm{pmol} / \mathrm{l} \mathrm{HGF}$ and $4 \mathrm{nmol} / \mathrm{l}$ activin A for $24 \mathrm{~h}$. The insulin-producing cells were then examined by immunocytochemistry. The triangular cell expressing GFP (green color) did not express insulin whereas the spindly cell not expressing GFP expressed insulin (orange color) at the end of the processes. B AR42J-B13 cells were co-transfected with cDNA for the constitutively active mutant of MAP kinase kinase and GFP. The cells were then incubated with $4 \mathrm{nmol} / \mathrm{l}$ activin $\mathrm{A}$ for $24 \mathrm{~h}$ and the insulin-producing cells were then examined. The cells expressing GFP also expressed insulin

these cells survived only a few days in the presence of activin $\mathrm{A}$ and HGF. When differentiated cells were then incubated with HGF alone, they survived for more than 7 days. In AR42J cells, HGF is not a mitogen [10]. In agreement with this notion, HGF did not increase the number of the cells under this condition. Instead, insulin content of the cells increased (Fig.7). Addition of wortmannin further increased the insulin content of the cells.

\section{Discussion}

Both exocrine and neuroendocrine properties are expressed by AR42J cells [7]. Upon treatment with a combination of activin A and HGF, AR42J cells differentiate into insulin-secreting cells within 3 days [10]. Although AR42J cells are tumour cells, they can differentiate into insulin-secreting cells via a programmed scenario. Being a clonal cell line, they provide a good experimental system to study the differentiation of beta cells, in particular, to study the signal transduction system responsible for the action of 
Table 1. Effect of transfection of cDNA for MAP kinase phosphatase, constitutively active MAPKK and dominantly negative PI 3-kinase on the differentiation of AR42J cells

\begin{tabular}{llllr}
\hline Transfected genes & \multicolumn{2}{c}{ Cell number $(\%)$} & & \\
\cline { 2 - 5 } & Cells studied & Positive for GFP alone & Positive for insulin alone & Double-positive \\
\hline MAP kinase phosphatase & $980(100)$ & $245(25.0)$ & $499(50.9)$ & $0(0)$ \\
Constitutively active MAPKK & $955(100)$ & $33(3.5)$ & $0(0)$ & $143(14.9)$ \\
Dominantly negative PI3K & $932(100)$ & $98(10.5)$ & $476(51.0)$ & $136(14.5)$ \\
\hline
\end{tabular}

AR42J cells were transfected with cDNA for MAP kinase phosphatase, constitutively active MAPKK or dominantly negative p85 of the PI 3-kinase. Cells transfected with MAP kinase phosphatase and dominantly negative $\mathrm{p} 85$ were incubated with $100 \mathrm{pmol} / \mathrm{l} \mathrm{HGF}$ and $4 \mathrm{nmol} / \mathrm{l}$ activin A for $24 \mathrm{~h}$. Cells transfected with constitutively active MAPKK were incubated with $4 \mathrm{nmol} / \mathrm{l}$ activin A alone for $24 \mathrm{~h}$. Cells were then immunostained with anti-insulin antibody. The number of cells positive for GFP alone, insulin alone and both were counted

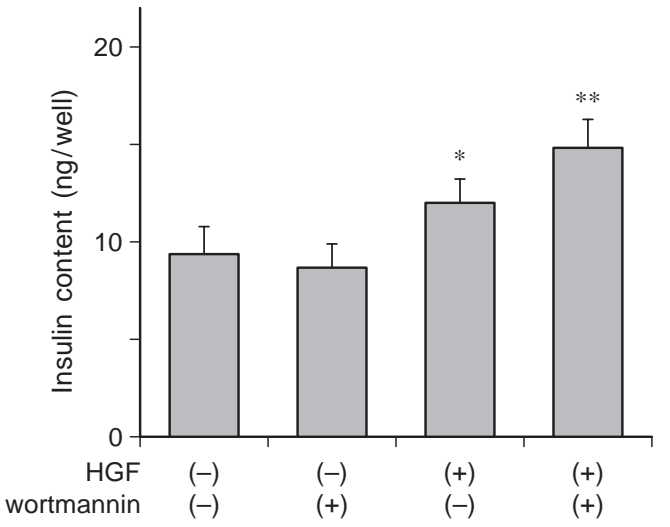

Fig. 7. Insulin content of the cells treated with HGF. AR42JB13 cells were incubated for 3 days with $100 \mathrm{pmol} / \mathrm{l} \mathrm{HGF}$ and $4 \mathrm{nmol} / \mathrm{l}$ activin A. Cells were then washed twice with DMEM and were then incubated for 5 days in DMEM containing $0.5 \% \mathrm{FCS}$ with $100 \mathrm{pmol} / \mathrm{l} \mathrm{HGF}$ in the presence or absence of $50 \mathrm{nmol} / \mathrm{l}$ wortmannin. As a control, cells pretreated with activin $\mathrm{A}$ and $\mathrm{HGF}$ were further incubated for 5 days in DMEM containing $0.5 \%$ FCS. The insulin content of the cells was then measured. Values are the means \pm SD for four experiments. ${ }^{*} P<0.05$ vs none, ${ }^{*} * P<0.05$ vs $\mathrm{HGF}$ alone

differentiation factors. In our study, we examined the signal transduction pathways involved in the HGFmediated differentiation. In AR42J cells, HGF elicited three different actions: firstly, it blocked apoptosis induced by activin A; secondly, it converted AR42J cells into insulin-secreting cells; and thirdly, it increased the insulin content of the AR42J cells already committed to differentiation.

Hepatocyte growth factor activated both MAP kinase and PI 3-kinase. When PD098059 or wortmannin was added together with HGF, only PD098059 blocked the differentiation. Since inhibition of MAP kinase activity correlates well with the attenuation of differentiation, it is probable that the MAP kinase activation is necessary for the HGF-induced differentiation. Consistent with this notion, introduction of the cDNA for MAP kinase phosphatase, which inactivates MAP kinase [21], blocked HGF-induced differentiation. Furthermore, transfection of cDNA for constitutively active mutant of MAPKK led to differ- entiation. Taken together, these results indicate that activation of MAP kinase pathway is necessary and sufficient for HGF action on differentiation of AR42J cells into insulin-secreting cells. These results corroborate earlier reports that activation of the MAP kinase is necessary and sufficient for differentiation of PC12 cells by nerve growth factor [25, 26]. In AR42J cells, other ligands which did not induce differentiation also activated MAP kinase, for example, EGF- and insulin-activated MAP kinase. One difference between the actions of HGF and these ligands is that the latter induced only a transient activation of the MAP kinase. The EGF-induced activation of MAP kinase peaked at $30 \mathrm{~min}$ but returned to the basal value by 60 min whereas HGF activated the MAP kinase for at least $3 \mathrm{~h}$. In PC12 cells, nerve growth factor induces sustained activation of the MAP kinase whereas EGF, which does not induce differentiation in these cells, activates the MAP kinase only transiently [27]. Hence, sustained activation of the MAP kinase is possibly a prerequisite for the induction of differentiation. Alternately, HGF but not EGF may induce translocation of the MAP kinase into the nucleus as shown in other cells [28]. Activin-induced apoptosis in AR42J cells is reversed by HGF (Fig.3). When $100 \mu \mathrm{mol} / 1$ PD098059, which completely blocks MAP kinase activation by HGF, was added together with HGF and activin A, the viability of AR42J reduced considerably. This result indicates that the HGF action on the prevention of apoptosis requires the activation of MAP kinase. Hence, MAP kinase mediates the protection of apoptosis and induction of differentiation into insulin-secreting cells. Note that the activation of PI 3-kinase is possibly also required for the HGF action on the prevention of apoptosis. In our system, HGF did not increase the activities of other members of the MAP kinase, for example cJun aminoterminal kinase or p38 (data not shown).

In AR42J cells, blocking the PI 3-kinase did not inhibit HGF-induced conversion into insulin-secreting cells. This notion is supported by two means: wortmannin which blocks PI 3-kinase effectively [20] did not block HGF-induced differentiation and transfection of cDNA for the dominantly negative mutant of 
p85 subunit of the PI 3-kinase [23] did not block the HGF action. Therefore, HGF induces differentiation of AR42J cells by a mechanism independent of PI 3kinase, whereas, inhibition of PI 3-kinase activity enhances the effect of HGF on insulin content of already differentiated AR42J cells. It has been reported that in human ICC, blockers of the PI 3-kinase enhanced differentiation of ICC into insulin-secreting cell [24]. That report showed that PI 3-kinase inhibitors increased the number of insulin-positive cells and the insulin content of ICC. The apparent difference in the results of the two studies could result from the difference in the properties of two cell systems, i.e. primary cells compared with tumour cells. Alternately, AR42J cells and ICC could represent different steps of differentiation. The second may consist of mixed cell populations and even though most of the cells are negative for insulin, they are probably already committed to differentiation into endocrine lineage. In contrast, AR42J cells are not committed to differentiation into endocrine cells unless activin $\mathrm{A}$ is added exogenously $[8,9]$. Before treatment with activin A, AR42 J cells express amylase and carbonic anhydrase, markers of acinar and ductal cells, respectively. Possibly AR42J cells are a model in which we can observe an early step of endocrine determination. Once committed to differentiation into insulin-producing cells, PI 3-kinase activity is inhibitory for the maturation of differentiated AR42J cells. If this is the case, our results are in agreement with the earlier results [24].

Acknowledgements. Our study was supported by Grant-in-Aid from the Ministry of Education, Science, Sports and Culture of Japan and grants from the Japanese Pancreatic Foundation, the Japanese Diabetic Foundation, the Novartis Foundation of Japan, the Uehara Foundation, the Life Science Foundation, and the Yamanouchi Foundation for Research on Metabolic Disorders. Authors thank Dr. M. Kasuga and Dr. E. Nishida for providing us with cDNA for dominantly negative mutant of p85 of PI 3-kinase and cDNAs encoding for MAP kinase phosphatase and constitutively active mutant of MAP kinase kinase, respectively. Authors also thank Dr. A. Saltiel for providing PD098059. Authors are grateful to M. Ozeki for technical assistance and M. Odagiri for secretarial assistance in preparation of the manuscript.

\section{References}

1. Pictet RL, Clark WR, Williams RH, Rutter WJ (1972) An ultrastructual analysis of the developing embryonic pancreas. Dev Biol 29: 436-467

2. Teitelman G (1991) Cellular and molecular analysis of pancreatic islet cell lineage and differentiation. Recent Prog Horm Res 47: 259-297

3. Jonsson J, Carlsson C, Edlund T, Edlund H (1994) Insulin-promoter-factor 1 is required for pancreas development in mice. Nature 371: 606-609

4. Ahlgren U, Pfaff SL, Jessell TM, Edlund T, Edlund H (1997) Independent requirement for ISL1 in formation of pancreatic mesenchyme and islet cells. Nature $385: 257-260$

5. Sosa-Pineda B, Chowdhury K, Torres M, Oliver G, Gruss P (1997) The $\mathrm{Pa} \times 4$ gene is essential for differentiation of insulin-producing $\beta$ cells in the mammalian pancreas. Nature 386: 399-402
6. St-Onge L, Sosa-Pineda B, Chowdhury K, Mansouri A, Gruss P (1997) $\mathrm{Pa} \times 6$ is required for differentiation of glucagon-producing $\alpha$-cells in mouse pancreas. Nature 387: 406-409

7. Christophe J (1994) Pancreatic tumoral cell line AR42J: an amphicrine model. Am J Physiol 266:G963-G971

8. Ohnishi H, Ogushi N, Tanaka S et al. (1995) Conversion of amylase-secreting rat pancreatic AR42J cells to neuron-like cells by activin A. J Clin Invest 95: 2304-2314

9. Mashima H, Ohnishi H, Wakabayashi K et al. (1996) Betacellulin and activin A coordinately convert amylase-secreting AR42J cells into insulin-secreting cells. J Clin Invest 97: 1647-1654

10. Mashima, H, Shibata H, Mine T, Kojima I (1996) Formation of insulin-producing cells from pancreatic acinar AR42J cells by hepatocyte growth factor. Endocrinology 137: 3969-3976

11. Zarnegar R, Michalopoulos GK (1995) The many faces of hepatocyte growth factor: from hepatopoiesis to hematopoiesis. J Cell Biol 129: 1177-1180

12. Matsumoto K, Nakamura T (1996) Emerging multipotent aspects of hepatocyte growth factor. J Biochem 119: 591-600

13. Otonkoski T, Mally MI, Hayek A (1994) Hepatocyte growth factor/ scatter factor has insulinotropic activity in human fetal pancreatic cells. Diabetes 43: 947-953

14. Otonkoski T, Cirulli V, Beattie GM et al. (1996) A role for hepatocyte growth factor/scatter in fetal mesenchyme-induced pancreatic $\beta$-cell growth. Endocrinology 137: 3131-3139

15. Alessi DR, Cuenda A, Cohen P, Dudley DT, Saltiel AR (1995) PD098059 is a specific inhibitor of the activation of mitogen-activated protein kinase kinase in vitro and in vivo. J Biol Chem 270: 27489-27494

16. Zhang, YQ, Kanzaki M, Mashima H, Mine T, Kojima I (1996) Norepinephrine reverses the effects of activin A on DNA synthesis and apoptosis in cultured rat hepatocytes. Hepatology 23: 288-293

17. Ferby IM, Waga I, Sakanaka C, Kume K, Shimizu T (1994) Wortmannin inhibits mitogen-activated protein kinase activation induced by PAF in guinea pig neutrophils. J Biol Chem 269: 30485-30488

18. Sato T, Fantl WJ, Escobedo JA, Williams LT, Kaziro Y (1993) Platelet-derived growth factor receptor mediates activation of Ras through different signalling pathways in different cell types. Mol Cell Biol 13: 3706-3713

19. Prasher, DC (1992) Primary structure of the Aequorea victoria green-fluorescent protein. Gene 111: 229-233

20. Okada T, Sakuma L, Fukui Y, Hazeki O, Ui M (1994) Blockage of chematactic peptide-induced stimulation of neutrophils by wortmannin as a result of selective inhibition of phosphatidylinositol 3kinase. J Biol Chem 269: 3563-3567

21. Sun H, Charles CH, Lau LF, Tonks NT (1993) MKP-1 (3CH134), an immediate early gene product, is a dual specificity phosphatase that dephosphorylates MAP kinase in vivo. Cell 75: 487-493

22. Fukuda M, Goto Y, Nishida E (1997) Interaction of MAP kinase with MAP kinase kinase: its possible role in the control of nucleocytoplasmic transport of MAP kinase. EMBO J 16: 1901-1908

23. Sakane H, Ogawa W, Takata M et al. (1997) Phosphoinositide 3-kinase is require for insulin-induced but not for growth hormone- or hyperosmolarity-induced glucose uptake in 3T3-L1 adipocytes. Mol Endocrinol 11: 1552-1562

24. Ptasznik A, Beattie GM, Mally MI, Cirulli V, Lopez A, Hayek A (1997) Phosphatidylinositol 3-kinase is a negative regulator of cellular differentiation. J Cell Biol 137: 1127-1136

25. Cowley S, Paterson H, Kemp P, Marshall CJ (1994) Activation of MAP kinase kinase is necessary and sufficient for PC12 differentiation and for transformation of NIH3T3 cells. Cell 77: 841-852

26. Pang L, Sawada T, Decker SJ, Saltiel AR (1995) Inhibition of MAP kinase kinase blocks the differentiation of PC-12 cells induced by nerve growth factor. J Biol Chem 270: 13585-13588

27. Nguyen T, Scimeca JC, Filloux C, Peraldi P, Carpentier JL, Van Obberghen E (1993) Co-regulation of the mitogen-activated protein kinase, extracellular signal-regulated kinase-1, and 90-kDa ribosomal S6 kinase in PC12 cells. J Biol Chem 268: 9803-9810

28. Lenormand P, Sardet C, Pages G, Allemain GL, Brunet A, Pouyssegur J (1993) Growth factors induce nuclear translocation of MAP kinases but not of their activator MAP kinase kinase in fibroblasts.Cell 122: 1079-1088 